\title{
The status of wildlife in Tonga
}

Dieter Rinke

When the author visited 'Eua in the Tonga islands to study the red shining parrot, he took the opportunity to collect information on some other aspects of Tonga's wildlife. During his 18-month survey he also visited several other islands in the group. Here he discusses six rare and threatened animals-four birds and two reptiles.

The Kingdom of Tonga consists of 169 small oceanic islands with a land mass of barely $700 \mathrm{sq}$ $\mathrm{km}$, scattered over an area of 10,000 sq $\mathrm{km}$ in the south-west Pacific. The islands are of two types. The coral islands, mostly raised coral reefs, rarely exceed $100 \mathrm{~m}$ in altitude and are densely populated, but not very fertile. In contrast, the volcanic islands are sparsely populated because they are still volcanically active and have access difficulties. About 100,000 people live on 45 islands, but the population is growing rapidly.

Tonga's small fauna has been poorly studied, and only the distribution of birds is reasonably well known (Watling, 1982). Little has been published on the life histories of Tongan wildlife, on the degree of habitat destruction in the islands, and on the status of plant and animal species. There are only three species of native mammals (of which the Polynesian rat Rattus exulans certainly is an aboriginal introduction), 20 species of land and freshwater birds, many of which show a disrupted distribution within the archipelago, and about 11 species of reptiles. Four species of birds have been introduced in this century, and the black and brown rats Rattus rattus and $R$. norvegicus have been accidentally introduced on most of the inhabited islands.

The island of 'Eua, which is the oldest island in the 146 archipelago, has the most diverse flora with more than 300 species of native vascular plants (Yuncker, 1959), about 10 of these being endemic to the island. The relatively young volcanoes of Late and Niuafo' ou have about 150 species of plants, none of which is confined to these islands (Yuncker, 1959; Sykes, 1981). The flora of the low coral islands is poor in species; endemism occurs only on the large islands of Tongatapu and Vava'u.

\section{Account of rare and threatened species}

\section{Niuafo' ou megapode}

This megapode, Megapodius pritchardii, is endemic to Niuafo'ou, Tonga's northernmost island, and is Tonga's only endemic bird. Rinke (1986) gives an account of certain aspects of its biology. It lays its eggs in loose soil and gravel associated with warm volcanic ducts, where the chicks will hatch after about three months at 30 $32^{\circ} \mathrm{C}$. These unusual nesting habits make it the best-known bird species of Tonga (Todd, 1978; Weir, 1973). Surprisingly, the Niuafo'ou megapode is not listed in the ICBP Bird Red Data Book (King, 1979).

Megapodes are largely confined to the forests covering the inner slopes of the crater of Niuafo' ou and the islands within the central lake. They are rarely encountered in forested areas elsewhere, hence their range is exceedingly small (about 5-10 sq km).

Human pressure on adult megapodes is low and very few are captured in their nesting holes. The birds are extremely wary, and much more often heard than seen. Pressure on eggs and hatchOryx Vol 20 No 3, July 1986 


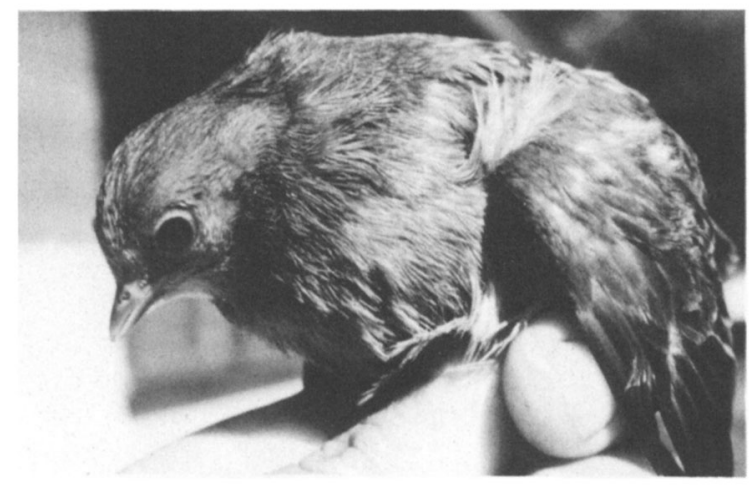

Newly hatched Niuafo'ou megapode, which was dug out of a nesting area close to the shore of the central lake (Dieter Rinke).

lings, however, is heavy, and only very few juveniles may leave the accessible nesting sites. Although the species is protected by law, there is no enforcement. The survival of the species depends mainly on breeding success in the inaccessible nesting areas.

Population estimates range from 2000 (Weir, 1973), to 200-400 (Todd, 1978); the latter seems more reliable. Niuafo'ou people reported that more than 100 eggs can be collected at each breeding site in one year.

Local chiefs prohibited the collecting of megapode eggs, hatchlings and adults after the disastrous volcanic eruption in 1891, when the species was nearly exterminated (Friedländer, 1899). It is doubtful whether the native people nowadays would adopt such protective measures, as the system of local chiefs is in disorder, and Niuafo'ou is administered by Tongatapu civil servants.

\section{Blue-crowned lory}

Blue-crowned lories Vini australis occur in the southern Lau islands, Fiji, in Samoa (except for Tutuila) and in Tonga. The species has disappeared from most of the inhabited Tonga islands during this century, probably because of the depredations of the introduced black rat; blue-crowned lories are thriving on islands that

Figure 1. Map of the Kingdom of Tonga. Small islands in the Ha'apai group (indicated by numbers): 1, Fotuha'a; 2 , Uoleva: 3, 'Uiha: 4, Ha'afeva; 5. Tungua.

Status of wildife in Tonga

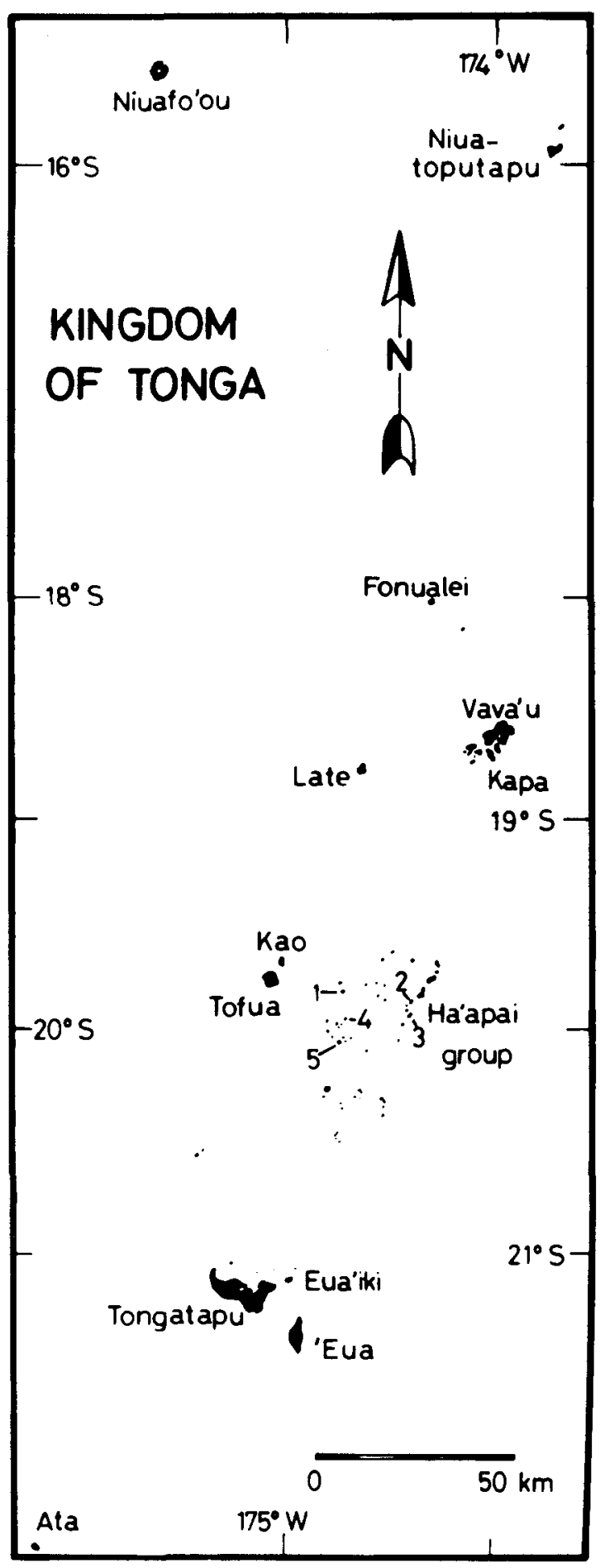

147 
are free of this rodent (Rinke, 1985). The population on Niuafo'ou numbers several thousand pairs. It is also reported as being abundant on Niuatoputapu (Carlson, 1974).

It became extinct on Tongatapu, on 'Eua, on Vava'u, and on several islands of the Ha'apai group during this century, having occurred there at the end of the 1800s (Layard, 1876; Finsch, 1877). Older people on 'Eua could well remember the blue-crowned lory, which they call henga, and say that it disappeared 50 years ago. The Whitney South Seas expedition collected the species on Tofua, Tungua, 'Uiha, Fotuha'a, Ha'afeva and Uoleva in the Ha'apai group (Amadon, 1942), and Carlson (1974) confirmed its existence on 'Uiha, Tungua and Ha'afeva. It may still occur on other, more remote, islands of the Ha'apai group, and on Late.

The blue-crowned lory has a wider range than the other species of the genus in the Pacific, and thus does not seem to be endangered. Unfortunately, the jungle mynah Acridotheres fuscus has recently colonized the island of Niuafo' ou, apparently without human assistance, and may compete with the lories for nesting sites (Rinke, 1986). Mynahs are likely to spread through the islands of Fiji, Tonga and Samoa by natural means as their population numbers are very high on certain Fiji islands. Hurricanes, which often occur in this region, may aid their dispersal. Another potential danger for blue-crowned lories, avian malaria, could spread easily since domestic flights are increasing and airstrips are built on even the smallest islands.

\section{Red shining parrot}

Red shining parrots Prosopeia tabuensis were introduced from Fiji to the Tonga islands of Tongatapu, where it is extinct now as a result of large-scale deforestation, and 'Eua in pre-European times.

Red shining parrots (called koki locally) are abundant in 'Eua, in forests, at the forest edge in the eastern parts, and in deep, heavily forested gullies. They are also often seen in plantation areas and in beach forest. The population is estimated at 1000 individuals ( \pm 50 per cent).

The main food item of the koki is the nutmeg 148

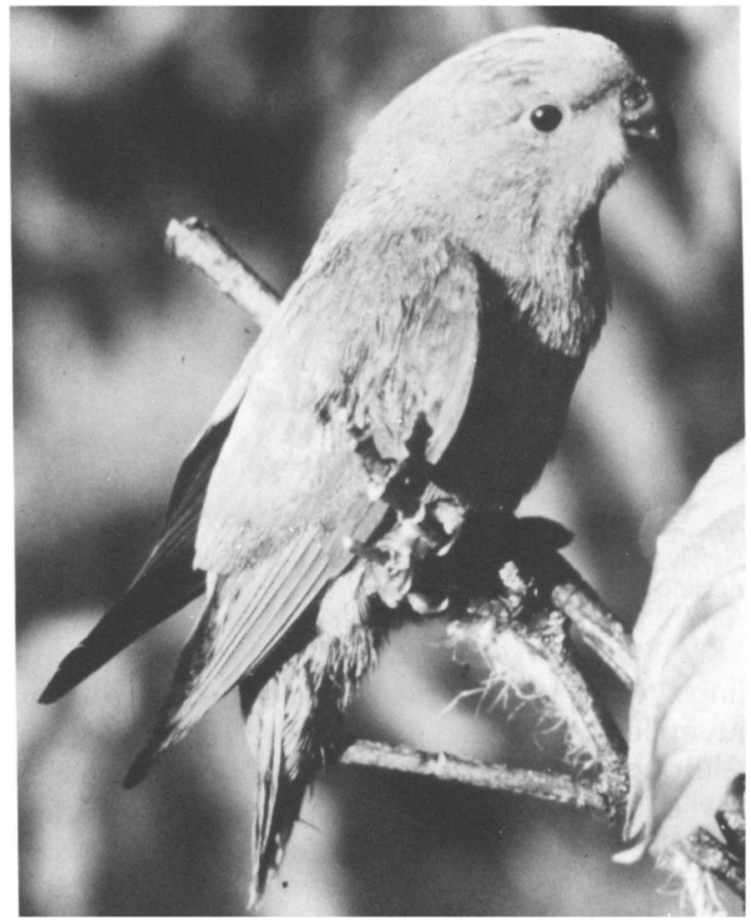

Juvenile blue-crowned lory (Dieter Rinke)

Myristica hypargyraea, which fruits continuously, but more than 30 species of food plants were identified (D. Rinke, in preparation). Damage to agricultural crops, such as bananas, corn, and pawpaws, seems to be overestimated by Tongan people, who consider the parrot an agricultural pest. I rarely observed the species feeding on these crops.

Red shining parrots need old hollow trees in forests or patches of remaining forest for nesting. The breeding success of birds in easily accessible and well-known parts of the island is nearly zero; young birds are taken shortly before they fledge. Sometimes even adults are caught in their nesting holes while feeding their offspring. Young kokis are normally kept as pets, but rarely survive 6 months on a diet of cooked starchy tubers of taro, yams or sweet potatoes. Adult birds are usually killed and eaten; their feathers are used for decorating Pandanus mats.

Due to the rapidly increasing deforestation of all accessible parts of 'Eua, the parrot will continue to decline. A small population may be able to Oryx Vol 20 No 3. July 1986 
persist in deep gullies and in the steep parts of the east coast.

\section{Tonga whistler}

The Tonga whistler Pachycephala pectoralis melanops is an interesting aberrant form of the wide-ranging Pachycephala pectoralis superspecies, which is distributed from Java in the west to American Samoa and Tonga in the east. In Tonga, it has been recorded only from the islands of Late, Vava'u, and some other small islets south of Vava' $u$, the combined land area of which does not exceed $130 \mathrm{sq} \mathrm{km}$.

During a one-week stay on Vava'u, I observed whistlers in two habitats: native forest on steep slopes on the northern and western coast, where

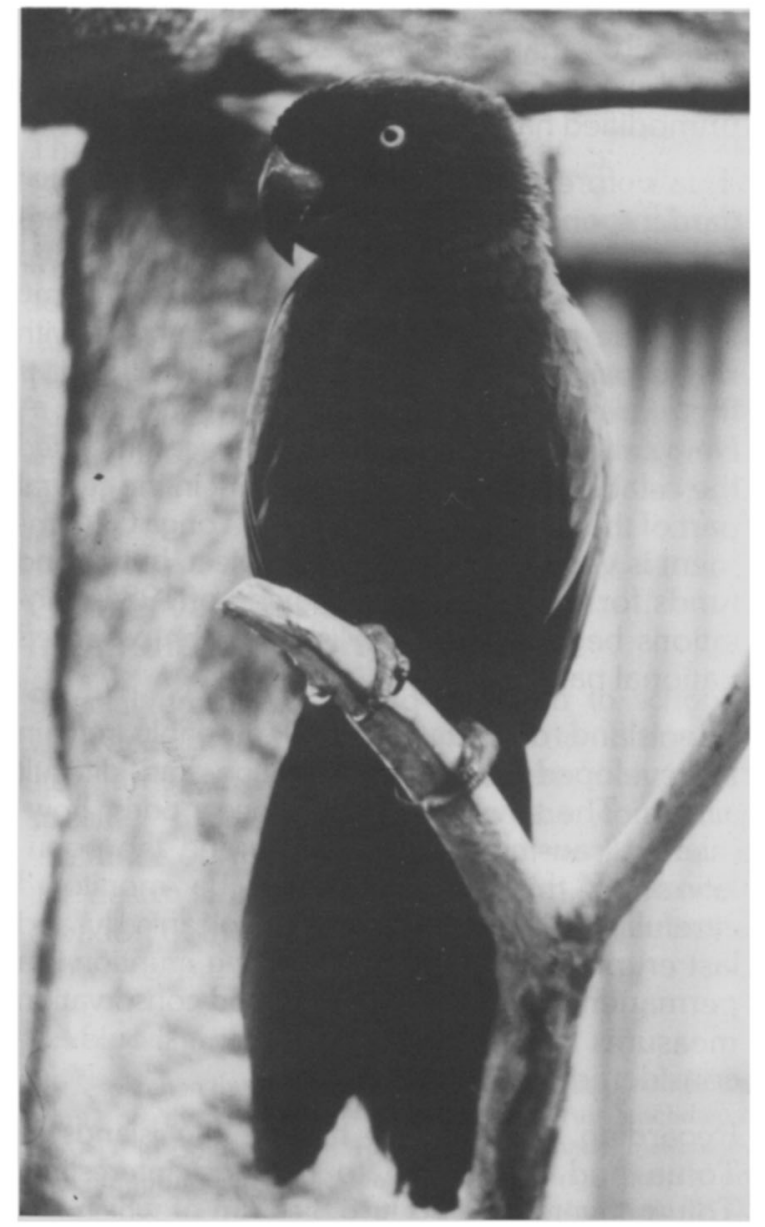

Red shining parrot (Dieter Rinke).

Status of wildlife in Tonga the species favours the zone above the beach forest, and at Mt Talau in the south. These forests are the most diverse plant communities on Vava'u; elsewhere plantations have replaced the native vegetation. Whistlers may also be found in forested pockets or regenerating bush in plantation areas.

The bird's loud, melodious whistling song can be used in estimating the population, which seems to be low in pockets of bush in cultivated areas, but high in the coastal forests. Only small numbers are thought to occur on the islets south of Vava'u (Euakafa, Ava and Kapa). On the rarely visited, uninhabited island of Late (17 sq $\mathrm{km}$ ), the whistler is certainly quite common, as there are considerable areas of broadleaved forest in the lower parts of the island (Sykes, 1981).

The Tonga whistler is probably not endangered, being well-established in the coastal forest zone on Vava'u, which is not very accessible, and possibly on Late too. The species shows some slight tendencies to adapt to man-modified habitats, so it might also survive in plantation areas where there is still some native scrub.

\section{Banded iguana}

The banded iguana Brachylophus fasciatus occurs in Fiji and in Tonga, but its distribution within the Tongan archipelago is poorly documented. All the existing museum specimens come from Tongatapu, but there are reports that the species exists on other islands in the Ha'apai, Vava'u and Tongatapu groups (Gibbons, 1981).

The banded iguana favours strand vegetation habitats. It can still be found in Tongatapu's coastal forest remnants, but is rarely encountered, even by the natives. Its long-term survival there must be considered precarious as a result of habitat destruction and human interference.

I could not find the iguana on 'Eua. Some of the island's inhabitants told me that it does not exist on 'Eua, but is common on 'Euaiki (1.1 sq km).

In the Ha'apai group, the banded iguana is reported to occur on several islands but it is rarely found. Except for the westernmost volcanoes of Kao and Tofua, the islands of the Ha'apai group are small, low, and of coralline origin. Even the 
smallest are regularly visited to collect coconuts, and their vegetation is almost totally altered by man, a thin line of beach vegetation being the only remnant of the native flora. The coconut plantations, however, often have a dense understorey of regenerating bush, especially on the smaller islands, which are visited more rarely. Nothing is known of the status of the iguana on such islands, but the existence of viable populations is possible.

On Vava'u, the banded iguana is said to favour Inocarpus edulis, Hernandina ovigera and Ficus sp. trees. Vava'u people tried to show me specimens on several occasions, mostly in village banyan trees, but unfortunately without success. The steep western and northern coasts of Vava'u, where coastal forest gradually grades into broadleaved forest, provide suitable habitat for the iguana.

The Tongans consider the banded iguana dangerous and even venomous, and so often kill them. Black rats and brown rats, which occur on most populated islands, probably take a high percentage of eggs and juveniles, while cats certainly prey upon adults.

\section{Tonga ground skink}

The Tonga ground skink Eugongylus microlepis was described by Dumeril and Bibron in 1839 from two specimens collected on Tongatapu, and which are now in the Paris museum (Greer, 1974). There have been no further records.

Despite extensive questioning with the aid of a photograph, I found no evidence to indicate that this skink still survives. Native people did not know of any ground dwelling reptile species this large (up to $35 \mathrm{~cm}$ ). Although the species would probably be very cryptic, as its congeners are, it should certainly be known by planters. If the type specimens really were collected on Tongatapu, the species must now be considered extinct.

\section{Conservation: problems and proposals}

Due to a rapidly growing human population, Tonga is in urgent need of plantation land for its 100,000 inhabitants. Remaining forested areas are thus very threatened; even remote islands are visited to establish plantations and to harvest the 150

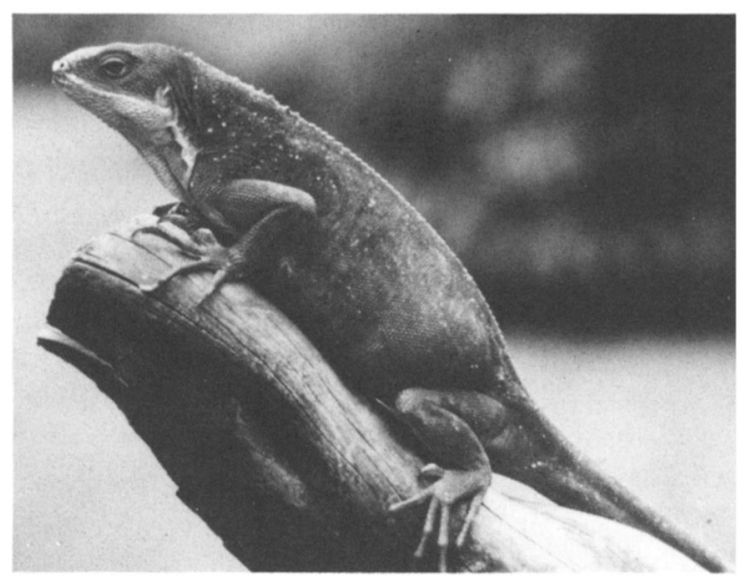

Female banded iguana, unbanded phase (Dieter Rinke).

crops. The islands of Tongatapu and Vava'u, and the coral islands of the Ha'apai group, are already altered by man to a large extent. Coastal forests and bush, mostly on steep slopes, are the only unmodified habitats.

'Eua's forests are being replaced by native gardens and exotic pine and eucalyptus plantations. Major changes in the vegetation occurred in the last decade and were continuing during my stay. The east coast of 'Eua is very rugged, with many parts being almost inaccessible, and it is therefore probably unsuitable for agriculture. A New Zealand forestry commission recommended the establishment of a national park in the central part of the island's east coast. The Tonga Government is very interested in this project, but has no funds for it, and at the beginning of 1984 plantations began to be established in the proposed national park area.

The island of Niuafo'ou will probably remain undeveloped due to its isolation and difficult access. The small number of megapodes, however, is causing some concern, and the population of this species should be monitored carefully. Niuafo'ou is still active volcanically, and last erupted in 1946. A devastating eruption is a permanent threat to the island, and conservation measures such as translocation should be considered.

Regarding their natural history, the islands of Tofua and Late seem to be most interesting. Tofua covers $55.4 \mathrm{sq} \mathrm{km}, 8 \mathrm{sq} \mathrm{km}$ of which is a central lake. About 100 people live on the island,

Oryx Vol 20 No 3. July 1986 
while the nearby volcanic cone of Kao, the highest peak $(1046 \mathrm{~m})$ in the Tongan archipelago, is uninhabited. The island of Late has an area of about $17 \mathrm{sq} \mathrm{km}$, is uninhabited and rarely visited. The habitats on Late and Tofua exhibit all stages of succession between bare lava flows and broadleaved forest, corresponding with the age of the volcanic ejecta. The flora of Late is one of the least modified plant communities in the South Pacific (Sykes, 1981).

Both islands have been rarely visited by scientists. A thorough investigation of their ecology is needed, and proposals should be made for their future management as nature reserves. The avifaunas of both islands are highly imbalanced, and the feasibility of translocating endangered or rare species of the region to one or both of these islands should be investigated, for example the Niuafo' ou megapode to Late, or the red shining parrot to Tofua.

The ICBP's project, Fiji: Survey of Seabird Colonies on Outlying Islands, should be extended to outlying uninhabited Tonga islands. Important seabird colonies can be expected on some volcanoes such as Fonualei, where I saw large numbers of seabirds on the voyage to Niuafo'ou, Hunga Ha'apai, Hunga Tonga, Kao, Ata, and especially on Tofua and Late, which again indicates the importance of these two islands.

\section{Conservation education is an immediate priority}

Special emphasis should be given to schools, where curricula are orientated to European standards and subjects, and are not island specific. The main threat to the continuing existence of wildlife and of man on small islands is the destruction of the native forests, so the preservation of these should be the main theme in the future conservation work on the islands.

\section{Acknowledgments}

My research in the Kingdom of Tonga was made possible by a grant of the Deutscher Akademischer Austauschdienst (DAAD) in Bonn, Federal Republic of Germany. Field work was supported by information from Tonga people on Niuafo'ou, Vava'u and 'Eua. I would like to thank Dr D. Watling, Suva, Fiji, Dr R. Sossinka and Mr W. Dreßen,

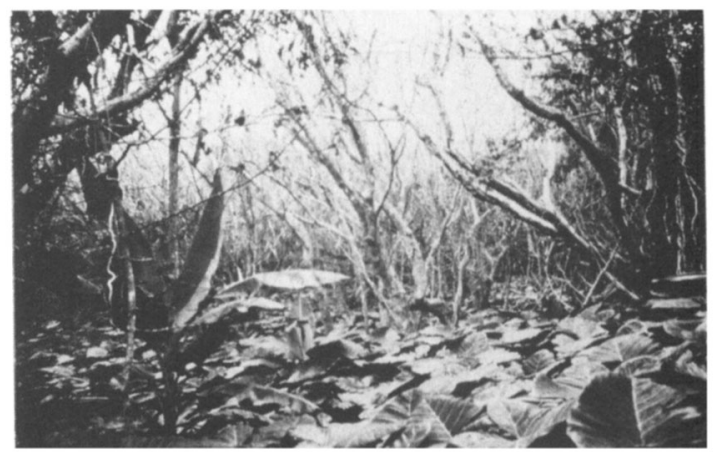

Newly established plantation on 'Eua. Kape Alocasia macrorrhiza and bananas are planted after burning the bottom of the trees, which may stand erect for several years (Dieter Rinke).

University of Bielefeld, for their comments on the draft of this paper.

\section{References}

Amadon, D. 1942. Birds collected during the Whitney South Seas expedition. L. Notes on some non-passerine genera. 2. Am. Mus. Nov. 1176.

Carlson, E.A. 1974. The avifauna of Tonga. Unpublished manuscript in the Fiji Museum, Suva.

Finsch, O. 1877. On a collection of birds from 'Eua, Friendly islands. Proc. Zool. Soc. London, 770-777.

Friedländer, B. 1899. Uber die Nestlöcher des Megapodius pritchardii auf der Insel Niuafu. Orn. Mon. Ber. 7, 37-40.

Gibbons, J.R.H. 1981. The biogeography of Brachylophus (Iguanidae) including the description of a new species $B$. vitiensis from Fiji. J. Herp. 15, 255-273.

Greer, A.E. Jr. 1974. The generic relationships of the scincid genus Leiolopisma and its relatives. Austr. J. Zool. Suppl. Series No. 31, 14-15.

King, W.B. 1979. Red Data Book, Vol. 2: Aves. Morges, Switzerland.

Layard, E.L. 1876. Notes on the birds of the Navigators' and Friendly islands, with some additions to the ornithology of Fiji. Proc. Zool. Soc. London, 490-506.

Rinke, D. 1985. Zur Biologie des Blaukäppchens (Vini australis), mit Bemerkungen zum Status der Maidloris (Gattung Vini). Trochilus, 6, 29-38.

Rinke D. 1986. Notes on the avifauna of Niuafo'ou island, Kingdom of Tonga. Emu, 86 (in press).

Sykes, W.R. 1981. The vegetation of Late island, Tonga. Allertonia, 2 (6), 323-353.

Todd, D.M. 1978. Preliminary study of Pritchard's Megapode, Megapodius pritchardii. Unpublished Report.

Watling, D. 1982. Birds of Fiji. Tonga and Samoa. Millwood Press, Wellington, NZ.

Weir, D. 1973. Status and habits of Megapodius pritchardit. Wilson Bull. 85, 79-83.

Yuncker, T.G. 1959. Plants of Tonga. B.P. Bishop Mus. Bull. 220, $1-280$.

D. Rinke, Department of Ethology, University of Bielefeld, $P O$ Box 8640, D-4800 Bielefeld 1, Federal Republic of Germany.

151 